\title{
The Role of the Church and the Christian Family Towards Widow Care as Highlighted by Paul
}

\author{
Miruka Philip ${ }^{1, *}$, Aloo Mojola ${ }^{1}$, Nathan Joshua ${ }^{2}$, Onginjo Mary ${ }^{1}$ \\ ${ }^{1}$ Great lakes University of Kisumu, Kenya \\ ${ }^{2}$ Africa International University, Kenya \\ *Corresponding Author: mirukaphilip@yahoo.com
}

Copyright $(\subseteq 2015$ Horizon Research Publishing All rights reserved.

\begin{abstract}
The number of women becoming widows has been increasing on daily basis due to the deaths of their husbands which are caused by various reasons such as HIV infections, accidents, old age and many others. After the death of their husbands, widows face challenges within the society and these affect their socio-economic development and spiritual growth in the society. However, despite these challenges facing widows, minimal efforts have been made by a number of churches today to care for widows. One of these churches is the Africa Inland church (AIC) in Kenya which was founded in 1895. The research therefore is an investigation of the practice of widow care in AIC Central lake Region. It also sought to investigate how the selected AIC churches are actively involved in the practice of widow care. The study revealed that the practice of widow care has not been fully implemented in the church. The reasons include; limited funds, administrative weakness, lack of visionary leaders and many others. The Bible absolutely supports widow care and so the church and the entire Christian fraternity are obliged to practice Widow Care in relation to the Biblical teachings.
\end{abstract}

Keywords Widow Care, Fraternity, Biblical

\section{Introduction}

There are numerous other issues which are of concern to the churches, particularly AIC congregations but the study focused on Widow Care among the selected AIC Congregations and its environs (non-Christian Luo widows). Several studies have revealed that widows undergo great agony and grief after the demise of their husbands. Woof asserts, "The urge to acquire material wealth controls the treatment of widows in the society; all other activities including levirate, may serve the same purpose. So mystification and rituals, superstitious practices are all geared towards the oppression of the widow more importantly for economic gains"1. This is contrary to the norm of the luo community in terms of caring for the widows as Odaga argues, "Widow Care was done as an expression of love and respect to the family of the deceased"2. The church has done very little to see to it that the needs of genuine widows are met appropriately. This study was conducted to identify how best widow care can be handled in relation to biblical principle. The Bible speaks highly of widows who desperately need the church's help and support from their relatives (1Tim 5:3-8 NIV).

\section{Methodology}

The investigative (exploratory) and exegetical research designs were used in this study. Christian and non-Christian Luo widows, lay leaders and Church ministers were selected for interview from the eight church districts of AIC Central Lake Region. Both secondary and primary sources were used to collect the data. Secondary sources included the published and unpublished materials: books, newspapers, articles, journals and internet. Primary sources used were: field data which was obtained through structured questionnaires, oral interviews, observation and content analysis. The collected data was then analyzed using qualitative and quantitative methods. After the analysis the data was then presented inform of the text.

\section{Results}

The study revealed that widows face various challenges. These include: Lack of material support, being held in low regard, cultural practice, lack of empowerment, fears and worries, temptations to defect to other denominations, side-lined in decision making, exploitation, and not actively involved in the ministry. The challenges facing the church are: Administrative weakness, poverty, burden of the church, limited funds and lack of visionary leaders. Some of the churches studied were exemplary on how they take care of the widows by initiating income generating projects to empower the widows. They also do table banking whereby the widows can borrow money for their self-substaince and 
therefore relieve the church from burden. Other studied churches are doing even more better by providing scholarship to the widows children. However, on the other hand many of the studied churches do very little in supporting the widows. Besides the church the community also participates in supporting the widows by providing them with foodstuffs through well-wishers and other support groups. The findings shows that the concept of widow Care has totally been misunderstood by people viewing it as an opportunity to exploit the widows and ritual-cleansing through sexual inter-course with the widow. One of the purposes of widow care was to express the love and respect to the deceased family and maintenance of the cultural norms that govern the luo community. The study showed that most of non-Christian Luo widows still uphold cultural practice of widow care through wife-inheritance. Furthermore, the study revealed that the Bible supports widow care and so the church is obliged to comply with the biblical truth.

\section{Discussion}

Challenges facing widows such as fears and worries make it difficult for some widows to resist giving in to other practices such as wife-inheritance. Potash argues, "many of them who have no source of income find it difficult to resist being inherited for fear of excommunication from their matrimonial homes without any entitlement to the estates of their deceased husbands" ${ }^{3}$. If the purpose of widow care was to express love to the deceased family then this practice should be adapted by the church and it is for this reason why Odaga says, "Widow Care was done as an expression of love and respect to the deceased family"(Ibid 1994:15). If the church practice this then it became part of the Africa community comply with the Christian teachings on Widow Care. The situation of the widows should steer-up the church from its comfort zone and a rise to fulfill its mandate by caring for the widows in relation to the Biblical principles. If the challenges facing the church are not adequately dealt with, the widows are likely to suffer. However, the church needs to ask itself whether the same challenges were experienced by the Early Church. Carter observes, "The apostolic church like the church of every subsequent generation had its problems" overlook the positive cultural norm that governed the luo community as Ojwang asserts, "Widow Care was done to enhance continuity of the deceased especially if the child was not left behind by the deceased for the luo, failing to perpetuate oneself by having children is a great misfortune" 5 . The church has the responsibility to adapt this practice because the Bible recommends that young widows to remarry if they cannot control their emotions (1Cor.7:9). This will reduce sexual-immorality both in the church and in the community. The theory of symbolic interaction that deals with people and their interaction with each other in the society is relevant to the study. Bulmer asserts that, "The term symbolic interaction presents three principles as its foundation. These include: How human beings acts towards things on the basis of the meaning that things have for them and what they convey; how people see themselves, others and their situation especially in time of death.

\section{Literature Review}

\section{Exegetical Interpretation of 1Timothy5:3-8}

During Paul's fourth missionary journey, he had instructed Timothy to care for the church at Ephesus (1 Tim.1:3) while he went on to Macedonia. However, when Paul realized that he might not return to Ephesus in the near future, he wrote this first letter to Timothy to develop the charge he had given Timothy before. In this chapter, Paul gives Timothy many instructions on how to deal with various groups of people within the church. He reiterates that it is the responsibility of overseers (elders) and pastors to reprove sin in the church and to discipline church members. However, it is never suitable to harshly rebuke an older person. Rather, the pastor should treat older people with the respect he would show to his own parents. Paul further explains that Timothy should advise and admonish younger members of the church as he would to his own brothers and sisters. He then changes his topic of discussion and focuses on widow care, saying that caring for widows is a very important Christian duty and so the church was obliged to take into consideration the welfare of widows in the church.

In 1Timothy 5:3-8, Apostle Paul instructs Timothy with regards to handling the problems with widows. This discussion is one of the most extensive on a particular subject in the entire epistle. This indicates that this was a significant problem in the Ephesians Christian community and therefore expresses urgency for this situation to be dealt with promptly and correctly. In this pericope, Paul identifies three different types of widows. First, are real widows who are in need and have no relatives to support them materially. Second are widows have relatives who can support them materially (1Tim.5:4).Third are widows who have a self-indulgent lifestyle (1Tim.5:6-7). Paul teaches that only the first group is to be supported materially by the Ephesians Christian community. However, as much as the church support the widows with the benevolence fund, they should be careful for their will always be those who are in need and those who want to take advantage. The relatives and the children of the second group were actually responsible to financially support this category of widows.

The third group was not worthy of any financial support. However, the fourth group in verse 9 to 14 Paul recommends to remarry and not only so, but to be supported by their husbands who will make sure that they are kept occupied so that they do not become busybodies and gossipers. The apostle did not want the church to waste its financial resources on people who were really not in need. These fourth groups of widows are the ones that propagate the spread of HIV/AIDS in the church and in the society. 
Adeyemo argues that, "More than 41 million people globally are living with HIV/AIDS and some $75 \%$ of them (30million) live in Africa" ${ }^{6}$. In 1Timothy5:3-8, Apostle Paul instructs Timothy about whom widows should be enrolled to receive benefits from the church and the widows who should not. This however, is not an official order of widows because this passage does not address the duties of widows but rather simply the qualifications that must be met by widows in order for them to be supported by the church

\section{Greek Lexicon Interpretation}

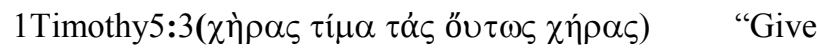
proper recognition to those widows who are really in need". This verse begins the pericope that ends in 1Timothy 5:16 and addresses the issue of which widows in the Ephesians Christian Community were eligible to receive financial aid from the church. It also contains the figure of asyndeton to emphasize the prohibition in 1Timothy 5:3 in the sense that Paul wants Timothy to dwell upon it and obey it. This figure emphasizes the importance of this command for the Christian community in Ephesus. Widow refers to a woman whose husband has died. According to the New Analytical Greek Lexicon the word 'widow' is translated chera

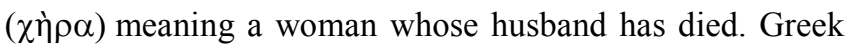

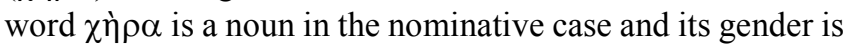
feminine. The Analytical Lexicon of Greek New Testament

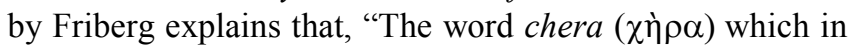
Hebrew is translated "bereft" conveys a sense of suffering loss or being left alone. However the term does not tell us how a woman becomes a widow and therefore the cause is not limited to a husband's death " 7 .

In the context of the Apostle, the word "widow 'specifically refers to a special category of widows, namely those who are not receiving financial and material support from their children or relatives. It refers to those who are in need materially because they do not have children to support them materially. 'Give proper recognition' implies, to providing for widows who have no children or relatives to support them as an expression of honoring them. It was done as an expression of love and respect to the family of the deceased. The Greek word $\tau \imath \mu \alpha \omega$ simply means to 'revere' or 'value'. The widows had to be honored if they met the qualifications that Paul later stated in 1Timothy 5:3 which is simply a reminder to Timothy to continue doing what they talked about before Paul left for Macedonia.

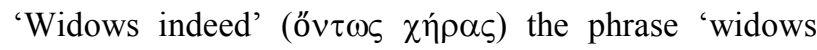
indeed' is qualified by the Greek term ovtos which is translated "desolate" which means having been left alone. It also indicates that no one is able to help her. The "widows indeed" refers to those widows who meet the qualifications presented by Paul in this chapter making them eligible for material aid from the church but does not deny that other widows are not in the normal sense of the word.

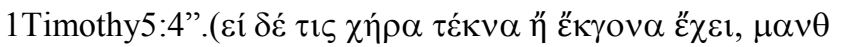

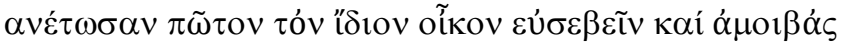

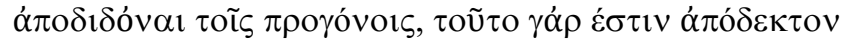

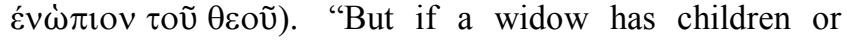
grandchildren, these should learn first of all to put their religion into practice by caring for their own family and so repaying their parents and grandparents, for this is pleasing to God". Verse 4 consists of two parts: Protasis which is the first part of a conditional sentence, whereas an apodosis is the second complementary part. The Protasis is 'if a widow has children or grandchildren,' and the apodosis is '[then] these should learn first of all to put their religion into practice by caring for their own family and so repaying their parents and grandparents, for this is pleasing to God'. Levisohn asserts that, "she is hypothetical, for it is speaking of those widows who have children or grandchildren who can support them in contrast to those mentioned in verse 3 who do not have children or relatives to support them" ${ }^{8}$. Therefore, it refers to a Christian widow who does not qualify to receive material aid from the Christian community in Ephesus. It is referring to a hypothetical Christian widow in order to teach a principle that is always applicable for Christians.

"Children" is the noun $\tau \varepsilon \kappa v o v$ which speaks of the offspring or children of the particular Christian widow or

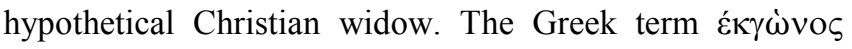
translated "nephews" means 'descendants' or 'grandchildren". The grandchildren here refer to the grandchildren of the Christian widows. These grandchildren are obliged to support their grandparents. In the African context the children and grandparents have to take the responsibility to care for their parents whether they are widows or not for in the luo community the physically dead are considered alive and is believed they can impose curses upon the living if they fail to care for the widows. Kirwen points out: "For the Luo's [sic] a person physically dead is still considered alive, present and capable of influencing the living. These relationships are seen to continue on intact through the barriers of physical death"10.

The apodosis indicates that children and grandchildren of widows must be taught to care for their parents and grandparents. This refers to the act of carefully communicating and instructing the children and grandchildren of widows in a face to face manner with regard to their responsibilities towards their parents. This would involve teaching them the implications of the commandment in Exodus 20:12 to honor one's father and mother. It is communicating the authoritative proclamation of Gods will to Christian children and grandchildren with respect to their responsibilities to their parents and grandparents, therefore, revealing their true spirituality in the context of family relationships.

According to Strong's Exhaustive Concordance of the Bible, the adjective 'first'( $\pi \rho \omega \dot{\tau} \tau)$ ) means "foremost", in time, place, order or importance(Strong's

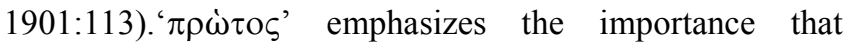
children and grandchildren of widows should learn through instruction to fulfill the financial duties to their parents. It also emphasizes that children and grandchildren should exercise godliness in their own family. 
The third part of 1Timothy 5:4 is the epexegetical clause where the verse explains in great detail the second part of

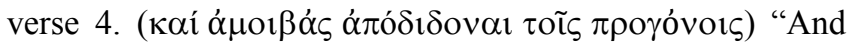
so repaying their parents and grandparents". This epexegetical clause explains in greater detail what Paul meant by his previous statement that children and grandchildren of widows are to exercise godliness with their own families by fulfilling material support to their parents and grandparents. This is a clear responsibility of the children for their parents including grandparents. Vines elaborates the word "repay" in his dictionary by saying, "The word "repay" is the Greek word ó $\mu$ or $\beta \dot{\alpha} \varsigma$ that means

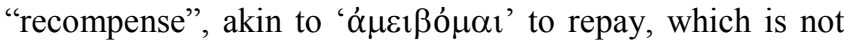
found in the New Testament is used with the verb ' $\alpha \pi$ ó $\delta$ เ $\delta \circ \mu ı \varsigma$ ' meaning to 'render'. In 1Timothy 5:4 this use is illustrated in the papyri by way of conferring a benefaction in return for something" ${ }^{11}$. This indicates that children are to give back a return to their parents which includes material support. Besides providing material items such as food, clothing and housing, parents also should give intangible assets such as love and encouragement to their children. This will give a great and happy privilege for children to also return a small measure of the tremendous support they have received from their parents.

Fourth, is the causal clause which is connected to the epexegetical clause and so presents the reason for the epexegetical clause and the apodosis.

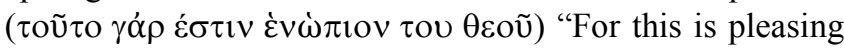
to God". The word ' $\varepsilon v \omega \pi i o v$ ', according to the New Analytical Greek Lexicon is an adjective and its gender is neuter and means 'insight' or 'in front', ' before', 'in the presence of', 'in front of' as in Luke 5:25, 8:47, Rev 4:5. The word $\theta \varepsilon o u$ is used to denote one true God and in Septuagint $\theta \varepsilon$ os translation of the Hebrew words 'Elohim' and 'Jehovah', former indicating his power and pre-eminence" ${ }^{12}$. The causal clause presents the reason why Paul wants the children and grandchildren of widows to fulfill their financial obligations to them. It indicates that fulfilling one's material obligations to one's parents and grandparents is pleasing and acceptable to the Father since this is in accordance with God the Father's will and also on exercise of godliness and honors him.

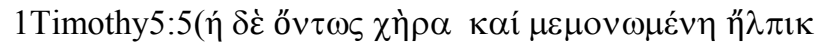

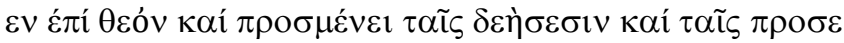

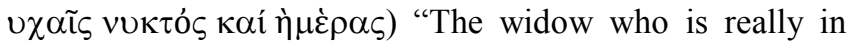
need and left alone puts her hope in God and continues night and day to pray and ask God for help"..The phrase "widows indeed' is the English equivalent of the Greek phrase őv $\tau \omega \varsigma \chi \eta ் \rho \alpha$ which is also translated as 'desolate' meaning 'having been left alone'. This also indicates that no one was able to help them. In ancient times widows were in an especially difficult position because honorable employment for them was not readily available. Perhaps some could receive help through family or friends but many lived in poverty never having received an inheritance. The outlook for many was a test whereby believers demonstrated the genuineness of their faith. In Paul's context the "widows who are really in need" refers to a widow who does not have children or relatives to support them materially. She is the widow who meets the qualification presented by Paul in this verse 5 making her eligible for material support from the church. "She who is left alone puts her hope in God" $(\mu \varepsilon \mu о \nu \omega \mu \varepsilon \dot{v \eta} \eta \not \lambda \pi i \kappa \varepsilon v \varepsilon \pi i$ $\theta \varepsilon \circ v)$. The Greek phrase

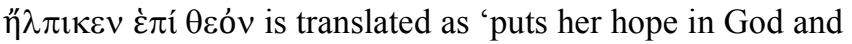
implies having confident expectation and has to do with the unseen and the future. The word $\eta \lambda \pi \iota \kappa \varepsilon v$ is in the perfect active indicative singular and it describes a true widow who confidently expects to receive logistical grace from God for example his provision to meet her daily needs (Matthew 6:25-34; Hebrews 13:5). The word also refers to her confident expectation of receiving God's rewards for faithful service because of her faith and good deeds in the past.

In 1 Timothy 5:6 the, statement (í $\delta \varepsilon \dot{\varepsilon} \sigma \pi \alpha \tau \alpha \lambda \tilde{\omega} \sigma \alpha \xi \tilde{\omega} \sigma$ $\alpha \tau \varepsilon \dot{\varepsilon} \theta \eta \kappa \varepsilon v$ ) which is translated as, 'But the widow who lives for pleasure is dead even while she lives'. Describes a widow who possesses a self-indulgent lifestyle. The verb $\sigma \pi \alpha \tau \alpha \lambda \omega$ speaks of a widow who is wealthy and lives an extravagant lifestyle. The Greek term for the verb ' $\sigma \pi \alpha \tau \alpha \lambda \alpha \omega$ ' means "to live riotously" which is also translated as 'given to pleasure'. It is derived from the word ' $\sigma \pi \alpha \tau \alpha \lambda \eta$ ' which means "luxury" (Ibid 1997:871). The New American Standard Version of New Testament Greek Lexicon defines the word ' $\sigma \pi \alpha \tau \alpha \lambda \alpha \omega$ ' with as "to live luxuriously, lead a voluptuous life giving into pleasure" ${ }^{13}$.Such widows that have a world centered vain life style and live riotously are not real widows and so they should not receive support from the church.

The self-indulgent lifestyle of this widow reflects her inward condition as one who is out of fellowship with God and living according to the lust of her indwelling sinful nature. It also reflects an inward condition of rejecting the word of God because of unbelief since disobedience to God is the result of unbelief. (Rev 22:11-12, Gal 6:7-8). This widow stands in direct contrast to the widow who possesses a confident expectation of blessing because of God's promises to provide for her and reward her for service for the body of Christ. The verb ' $\tau \varepsilon \theta v \eta \sigma \kappa \omega$ ' in the statement, which is translated as, 'she is dead while she lives' implies temporal spiritual death, in other words, out of fellowship with God. It is used of a Christian widow who is out of fellowship with God and as a result indulging in the desires of her sinful nature. This results in her living a self-indulgent lifestyle without regard for the needs of other less fortunate.

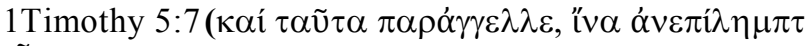
os $\tilde{\omega} \sigma ı v)$ says, 'Give the people these instructions too, so that no-one may be open to blame '. The Greek verb ' $\pi \alpha \rho \alpha \gamma \gamma \varepsilon \lambda \omega$ ' is a compound word that is composed of the preposition ' $\pi \alpha \rho \alpha$ ' meaning "beside" and the verb $\alpha \gamma \gamma \varepsilon \lambda \lambda \omega$ which means "to tell or announce". The compound verb $\pi \alpha \rho \alpha ́ \gamma \gamma \varepsilon \lambda \omega$ means "to proclaim or announce beside". The word actually speaks of passing a long a message or instructing someone in an authoritative manner. It is both a 
military and legal term describing a military command or an official summons to court " ${ }^{14}$. Louw defines the verb ' $\pi \alpha \rho \alpha \gamma \gamma \gamma \varepsilon \lambda \omega$ ' as "to announce what must be done to order" ( Ibid 1996:214).

Similarly, Friberg gives the following meanings, 'issuing a directive from an authoritative source, command, give strict orders, direct, instruct'(2000:294).The verb $\pi \alpha \rho \alpha \gamma \gamma \gamma \varepsilon \lambda \omega$, first appeared in 1Timothy 1:3, where it means, 'to command' and is to be used by Timothy as subject and false teachers in Ephesus as its object. Timothy was to command these false teachers to stop propagating false doctrine. It also implies clearly that Paul has delegated authority to Timothy to rebuke and hold those false teachers accountable. The word expresses the idea that Timothy is to stand before the Ephesians Christian community and officially and authoritatively communicate to them all that Paul taught them in 1Tim 4:6-10. In 1Tim 5:7, the verb $\pi \alpha \rho \alpha \gamma \gamma \gamma \varepsilon \lambda \omega$ means, 'to command' and is used with Timothy as its subject but this time it is used with reference to Paul's teaching in 1Timothy 5:3-6 specifically. It refers to Paul's command in verse 3 tí $\mu \alpha \mathrm{o}$ and in verse $4 \mu \alpha v \theta \alpha \nu \omega$. This terms mean that Timothy was to command compliance to the things Paul taught in verse 3 and 4 that is to honor widows by supporting those who are qualified to receive material support. It also means that Timothy is to command the Ephesians' Christian community to instruct their children and grandchildren with regards to their responsibility to support their parents and grandparents as stated in Exodus 20:12.

The $\pi \alpha \rho \alpha ́ \gamma \gamma \varepsilon \lambda \omega$ is "customary present imperative" whose force is for Timothy to continue commanding the Ephesians' Christian community to comply with Paul's instructions in 1Timothy 5:3-6 and specifically to comply with his commands in verse 3 and 4 . The present imperative is a command for action to be continued, action that may or may not have already been going on. It is often a character building command to the effect of making this habit by training oneself in this discipline. This is the use of present imperative in general precepts. "So that they may be above

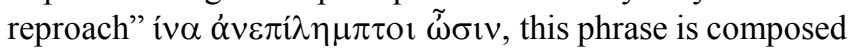
of conjunction $i v \alpha$, 'so that' or 'in order that'. The nominative masculine plural form of the adjective

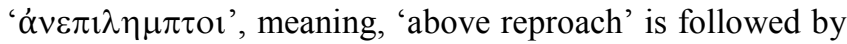
the present active subjunctive form of the verb, 'cí $\mu$ í ', 'they may be'. The verb, cífí means 'to be' in the sense of possessing a particular characteristic. It indicates that the Ephesians Christian community was expected to possess the characteristics of being beyond reproach.

The tense of the verb cí $\mu$ í is a customary or stative present for it is used to signal an on ongoing state. The active voice is also stative indicating that the subject exists in the state indicated by the verb 'cíní '. This indicates that Paul wants the Ephesians to comply with his commands in verses 3 and 4 in order that they would all exist in a state of being irreproachable. The subjunctive mood of the verb is employed with conjunction ' $v \alpha$ ' meaning ' in order that' and is used to introduce a purpose clause emphasizing the intention of the action of the verb whether accomplished or not. It does not imply any doubt about the fulfillment of the verbal action on the part of the speaker. The purpose clause, 'in order that they will be irreproachable in character,' emphasizes the intention of the preceding command for it presents Paul's purpose for Timothy to obey his previous command to continue making it his habit of commanding the Ephesians to obey the commands in verse 3 and 4.

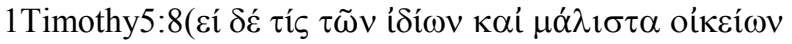

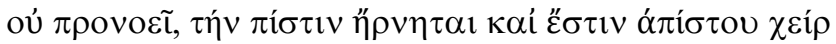
$\omega v)$ "If anyone does not provide for his relatives and especially for his immediate family, he has denied the faith and is worse than an unbeliever". .The word ' $\pi \rho 0 v o \varepsilon \omega$ ' means to have in mind to do; to provide for, care for, take care of. Louw explains that, "The verb $\pi \rho 0 v o \varepsilon \omega$ is a compound word which is composed of the preposition 'pro' which means 'before' and the verb voew which means 'to take thought'. In later writings among the Greeks and Septuagint it also could mean to care for, provide or be concerned about" (1996:220). The word appears only three times in the New Testament (Rom12:17, 2Cor 8:21, 1 Tim5:8). In the above verses, the verb ' $\pi \rho$ ovoe $\omega$ ' means, "To have regard for, take into consideration, carefully consider. The verb ' $\pi \rho \circ v_{0} \omega \omega^{\prime}$ in 1Timothy 5:8 is used of believers to provide materially for the widows who are in one's own extended family (grandparents) and immediate family (parents).

The word ' $\mu \alpha{ }^{\prime} \lambda \imath \tau \tau$ ' is an elative superlative adverb and appears a dozen times in the Greek New Testament (Acts 20:28, Galatians 6:10, Philippians 4:22, 1Timothy 4:10). Thayer gives the following meanings, 'to an unusual degree, most of all, especially, particularly' ( Ibid 1996:613). Louw and Nida define the word as, 'a very high point on a scale of extent', 'very much', 'particularly', exceptionally (louw and Nida 1996:280). In 1Timothy 5:8, the adverb ' $\mu \alpha$ ' $\lambda \imath \sigma \tau \alpha$ ' functions as a superlative adverb meaning, "especially" and is used to single out those who are members of a Christian immediate family such as parents and grandparents. It denotes an exact point on a scale of extent. The term is actually emphasizing the command for the Christians responsibility to care for their own parents and grandparents and even beyond one's own extended family.

The adjective "oikeios" is derived from "oikos" (oik $\omega \varsigma$ ) which means, "what is in or of a house, what belongs or related to a house or household'. Thus here in 1Timothy $5: 8$, the word denotes "one's own immediate family". Thus the Christian is to provide for those women in his own immediate family who are widows. The statement, 'He has denied the faith' is composed of articular accusative feminine singular. The noun ' $\tau \dot{\eta} v \pi i \sigma \tau \iota \varsigma$ ', "the faith" and is followed by the third person singular perfect middle indicative form of the verb 'ó $\rho v \varepsilon o \mu \alpha \imath$ ', 'he has denied". The verb ' $\alpha \rho v \varepsilon o \mu \alpha \imath$ ' means, 'to refuse'. However, at times it could mean, "To reject or to decline" and even, "to deny something or someone'. The word occurs only six times in 
the Septuagint and in Genesis 18:15 it is used of Sarah, "denying" that she laughed when the Lord promised that she and her husband would have a child a year later. The term also occurs 33 times in the New Testament.

In 1Timothy 5:8, the verb 'ó $\rho v \varepsilon o \mu \alpha \imath$ ' means "to reject" and its object is the articular noun ' $\pi$ i $\sigma \tau 1 \varsigma^{\prime}$ ' which denotes that body of doctrine taught by the Lord and the apostles. Thus, ' $\pi i \sigma \tau 1 \zeta$ ' is synonymous with the gospel and speaks of it as that which the church believes. Therefore, the verb refers to the Christian refusing to obey the teaching of the Lord and the apostles which constitutes the New Testament. The term speaks of the Christian refusing to obey the command to support the widows materially when they are in need. The noun ' $\pi$ i $\sigma \tau i s$ ' is used in an objective sense for the Christian faith. It refers to the content of what Paul taught the Gentile churches, in other words as a description of the gospel. It also refers to the gospel from the perspective of a body of doctrine or that which is believed by the church.

Commenting on the phrase, 'and is worse than unbeliever' Knight writes, "such a person is worse than an unbeliever, because Paul regards believers as having the word of the law written on their hearts and therefore even unbelievers are known to do instinctively the things of the law(Romans 2:14-15, 1Corinthians 5:1). Thus, for a professed believer who has God's law and fails to do what even many unbelievers do warrants the verdict that he is "worse than an unbeliever" Ibid ${ }^{9}$.

The conjunction koi is once again adjunctive, meaning that it is introducing a statement that presents an additional consequence of Christian failing to support members of his household who are widows and need material support. The word denotes 'an emphatic amplification' of the denial of Christian faith; the Christian who fails to provide for those widows in his immediate and extended family is worse than an unbeliever. The verb ' $\varepsilon i$ ' $\mu$ ' ' means, 'to exist in a particular state or condition' which is complemented by the expression

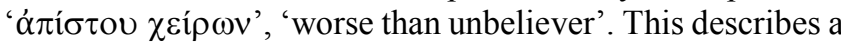
Christian who does not provide for the material needs of his parents and grandparents.

\section{Conclusions}

This study revealed that the survey AIC churches have done very little in relation to the practice of widow Care. The study found out that there are various challenges faced by the church which have incapacitated the church not to support the widows effectively. These challenges should be addressed adequately if the church desires to fulfill its mandate in Widow Care. There are numerous passages in the Old Testament and New Testament which supports Widow Care, such passages includes Mal.3:5 which state that those who oppress widows do not fear the almighty God. However, those who care for them are promised God's blessings (Jer.7:5-7). The early Church in Jerusalem was actively involved in the practice of widow Care whereby the needs of the Widows were met equitably (Acts 6:1ff.). Widows who were in the church and were without families to support them were to put on the church list to be supported by the church (1Tim.5:3-14). The practice of widow Care as a way of expressing love to the deceased family should be adapted into Christianity. However, the negative practices like ritual-cleansing to the set the widow free should be not be encouraged. If the church and family members fail to support the widows then they are likely to suffer and this may result into a dysfunctional society. However, the working widows should be encouraged to help supporting the widows so as to relieve the church from more burdens.

\section{REFERENCES}

[1] Woof, V. 1925. The Common Reader London: Hogarth Press.

[2] Odaga, A.B. 1994. Luo sayings. Kisumu: Lake publishers and enterprises Ltd.

[3] Potash, B.ed. 1986. Widows in African societies: choices and constraints. California Stanford university Press.

[4] Carter, W. The Wesleyan Bible Commentary. Grand Rapids, ML: William B. Eerdmans Publishing Company.

[5] Ojwang, H.J. 1999. How the luo marriages service death! In Gutema, Bekele and Daniel Smith eds.

[6] Adeyemo, Tokunboh. 2006. Africa Bible Commentary. A one volume commentary written by 70 African scholars. Word Alive Publishers. Nairobi.

[7] Friberg, T. 2000. Analytical Lexicon of Greek New Testament; Bakers Greek Testament Library. Grand Rapids, Mich: Bakers Books.

[8] Levisohn, Stephen H.2000. Discourse Feature of the New Testament Greek. A Course book on the information Structure of the New Testament Greek. Second edition. Dallas:SIL International.

[9] Knight III, George W.1992. The Pastoral Epistles: A Commentary on the Greek Text. The New International Greek Testament Commentary. Grand Rapids: Wm.B. Eerdmans Publishing Co.

[10] Kirwen, C. Michael. 1979. African widows. An empirical study of the problems of adapting western Christian feelings on marriage to the leviratic custom for the care of widows in four rural African societies. Orbis Books, Mary knolls: New York.

[11] Vines. W.E.1997. Expository Dictionary of Old and New Testament Words. Nashville Thomas Nelson Publication.

[12] Perschbacher, J.Wesley.1990. The New Analytical Greek Lexicon. Peabody: Massachusetts Hendrickson Publishers.

[13] Louw, Jeff.1996. Greek-English Lexicon of New Testament; Based on semantic Domains; Electronic e.d of the second edition. New York: United Bible Societies.

[14] Thayer, Joseph. 2003. Greek-English Lexicon of the New Testament. Peabody, Massachusetts, Hendrickson Publisher 